\title{
Host plants for mealybugs (Hemiptera: Pseudococcidae) in grapevine crops ${ }^{1}$
}

\author{
Fabiana Soares Cariri Lopes ${ }^{2}$, José Vargas de Oliveira², \\ José Eudes de Morais Oliveira ${ }^{3}$, Martin Duarte de Oliveira ${ }^{2}$, Adriana Maria de Souza ${ }^{4}$
}

\section{ABSTRACT}

Mealybugs (Hemiptera: Pseudococcidae) are considered pest insects of economic importance in grapevine crops. They are highly polyphagous, feeding on host plants of about 250 families. This study aimed to identify host plants for mealybugs in grapevine crops, in the São Francisco Valley region, Brazil. The samples included weeds, ornamentals, windbreaks, fruit trees and native plants of the Caatinga biome. A total of 37 species of host plants for mealybugs were identified, distributed in 18 families. The Malvaceae family was the most frequent one, with eigth host species identified, followed by Fabaceae with four and Euphorbiaceae with three. Most of these host plants are being recorded here for the first time in association with mealybugs species. From the identified plant species, 24 are hosts for Maconelicoccus hirsutus, 16 for Phenacoccus solenopsis, one for Ferrisia virgata, one for Dysmicoccus brevipes and one for Planococcus citri. The obtained results are important to better understand the host plant diversity for mealybugs, in order to implement integrated pest management programs.

KEYWORDS: Vitis vinifera, Pseudococcidae, Malvaceae, weeds.

\section{INTRODUCTION}

Mealybugs (Hemiptera: Pseudococcidae) are considered pests of economic importance in several crops in the world, such as grapevine (Morandi Filho et al. 2015, García Morales et al. 2016). The damage caused by sap-sucking mealybugs may lead to the consequent production of honeydew and the appearance of sooty mold, which makes fruits unfeasible for commercialization, and, in some

\section{RESUMO}

Plantas hospedeiras de cochonilhas-farinhentas (Hemiptera: Pseudococcidade) em cultivos de videira

As cochonilhas-farinhentas (Hemiptera: Pseudococcidae) são consideradas pragas de importância econômica em cultivos de videira. São altamente polífagas, alimentando-se de plantas hospedeiras de 250 famílias. Objetivou-se identificar plantas hospedeiras de cochonilhas-farinhentas em cultivos de videira, na região do Vale do São Francisco. Foram amostradas plantas daninhas, ornamentais, quebra-ventos, frutíferas e nativas do bioma Caatinga. Foram identificadas 37 espécies de plantas hospedeiras de cochonilhasfarinhentas, distribuídas em 18 famílias. A família Malvaceae foi a mais frequente, com oito espécies hospedeiras identificadas, seguida de Fabaceae com quatro e Euphorbiaceae com três. A maior parte destas plantas hospedeiras está sendo aqui registrada pela primeira vez em associação com cochonilhas-farinhentas. Das espécies de plantas identificadas, 24 são hospedeiras de Maconelicoccus hirsutus, 16 de Phenacoccus solenopsis, uma de Ferrisia virgata, uma de Dysmicoccus brevipes e uma de Planococcus citri. Os resultados obtidos são importantes para melhor conhecimento da diversidade de hospedeiros de cochonilhas-farinhentas, visando à implantação de programas de manejo integrado.

PALAVRAS-CHAVE: Vitis vinifera, Pseudococcidae, Malvaceae, plantas daninhas.

cases, quarantine restrictions may cause embargos in the export of in natura fruits (Kishino et al. 2007, Daane et al. 2008). Additionally, they can transmit viruses (grapevine leaf rolls) to host plants, such as Planococcus citri (Risso) (Cabaleiro \& Segura 1997, Cid et al. 2007, Daane et al. 2012).

Mealybugs are highly polyphagous insects and are reported in about 250 host families. The most common one is the Poaceae family, with 585 species already described, followed by Asteraceae

1. Received: Aug. 13, 2018. Accepted: Nov. 29, 2018. Published: Mar. 19, 2019. DOI: 10.1590/1983-40632019v4954421.

2. Universidade Federal Rural de Pernambuco, Departamento de Agronomia-Entomologia, Recife, PE, Brasil.

E-mail/ORCID: fabiana_cariri@hotmail.com/0000-0001-5429-0072, vargas.oliveira@uol.com.br/0000-0001-6976-6504, martinduarteoliveira@gmail.com/0000-0002-1385-9733.

3. Empresa Brasileira de Pesquisa Agropecuária (Embrapa Semiárido), Laboratório de Entomologia, Petrolina, PE, Brasil. E-mail/ORCID: eudes.oliveira@embrapa.br/0000-0002-9635-5097.

4. Universidade Federal do Piaú, Bom Jesus, PI, Brasil. E-mail/ORCID: adrianasouzabio@hotmail.com/0000-0001-5496-5834. 
(250), Fabaceae (225), Rosaceae (116), Rubiaceae (101), Euphorbiaceae (97), Myrtaceae (94), Labiatae (85), Moraceae (82) and Cyperaceae (75) (García Morales et al. 2016).

Weeds are often reported as hosts for different species of mealybugs, which can act as potential crop pests, such as Dysmicoccus brevipes (Cockerell) (Pandey \& Johnson 2006) and Pseudococcus viburni (Signoret) (Godfrey et al. 2003). Therefore, weeds in the growing area may increase pest infestation, what is a risk for the crop (Carvalho \& Costa 2014), and may, as well, decrease crop yield and increase production costs (Vasconcelos et al. 2012). The relative importance of the various weed species bordering crops as sources and reservoirs of mealybug populations has not yet been quantified (Pandey \& Johnson 2006). Other plant species that are close to crops may also act as hosts for mealybugs, as in the case of fruit trees and ornamental and windbreak plants.

The mealybugs species occurring in grapevines in the São Francisco Valley sub-region, Bahia state, Brazil, are Maconellicoccus hirsutus (Green, 1908), Planococcus citri (Risso, 1813), Phenacoccus solenopsis Tinsley, 1898, Dysmicoccus brevipes (Cockerell, 1893) and Ferrisia virgata Cockerell. Some of these species are directly associated with grapevine plants and can cause several damages, such as $P$. citri, D. brevipes and M. hirsutus, recently reported for this area (Lopes 2016). In the region, growers observed that, in addition to grapevines, these mealybug species is also found in other plants located in and around orchards, such as weeds, fruit plants, windbreak and ornamental plants, which can function as alternative hosts, serving as a refuge during the off-season crop and allowing a rapid infestation and population growth of mealybugs.

The identification of plants that may serve as hosts for mealybugs is essential, since they can serve as a reservoir for mealybugs during the period in which the main crop is not producing, and is one of the key requirements for an integrated management of pests (Maziero et al. 2007).

Knowing about alternative hosts for mealybugs shows the importance of the crop preventive inspection as one of the management tactics, because, when there is proof of the adaptability to new plants, the introduction of these pests in non-infested areas is facilitated by the traffic of people and machines, and also helps in the selection of ornamental plants (Benvenga et al. 2011).
This study aimed to survey species of host plants for mealybugs (Hemiptera: Pseudococcidae) in grapevine agroecosystems, in the São Francisco Valley sub-region, Brazil.

\section{MATERIAL AND METHODS}

The experiment was carried out in 19 table grape (Vitis vinifera) commercial producing areas, constituted of large and small properties, with plants at different production stages, in the São Francisco Valley region [Petrolina (PE), Lagoa Grande (PE), Casa Nova (BA), Juazeiro (BA) and Curaçá (BA)], Brazil, from May 2014 to June 2015.

The host plants were collected weekly in the selected areas with the greatest problems of high densities of these pest insects. Weeds, ornamentals, windbreaks, fruit trees and native plants of the Caatinga biome were observed, in and around grapevine crops. The host plants were collected randomly whenever there were mealybugs feeding on them by extracting sap from cells. Whole plants or parts, such as leaves, fruits and flowers, were stored in properly identified paper bags and sent to the laboratory for sorting and storage. These plants were identified and classified according to family, genus and species, by a specialist, based on Kissmann (1991) and Kissmann \& Groth (1992).

Mealybugs were collected at the same time as the plants were, and then taken to the laboratory for sorting and storage. For the identification of mealybugs, based on the morphological characters of adult females, about 10-20 specimens were stored in an eppendorf tube with $70 \%$ alcohol, duly identified and then sent for identification by Dr. Ana Lucia G. B. Peronti.

The preparation of the permanent slides drew on the technique described by Granara de Willink (1990), basically consisting of the following steps: 1) perforation of the specimens in the ventral region (3-4 holes with fine stilettos, such as needle tips); 2) clarification of the specimens in $10 \% \mathrm{KOH}$ solution in a water bath; 3) wash in distilled water; 4) dehydration in alcohol, alcoholic series: $70 \%$ and $100 \%, 15 \mathrm{~min}$ in each one; 5) exoskeleton coloring by adding only a few drops of fuchsine acid in insects still immersed in $70 \%$ alcohol; 6 ) after dehydration in $100 \%$ alcohol, finalization of clarification in eugenol (clove oil) for about $4 \mathrm{~h}$; 7) slide mount with Canada Balsam; and drying in oven. The insects were 
identified with an optical microscope (Williams \& Granara de Willink 1992, Granara de Willink 2009, Gullan et al. 2010, Kaydan \& Gullan 2012).

\section{RESULTS AND DISCUSSION}

In all, 37 species of host plants for mealybugs were identified, distributed in 18 families in grapevine agroecosystems. Most of the identified host species has here the first register of its association with mealybugs. The Malvaceae family was the most important (frequent) one among the families found, with 8 species identified, followed by Fabaceae (4) and Euphorbiaceae (3). These families constituted $40.5 \%$ of the plant species identified in this study (Figure 1). In the other families found, only one or two species were identified. The great diversity of host plant species available seasonally or annually in the grapevine agroecosystems offers shelter and food to the mealybug species of the region (Vennila et al. 2013) during the off-season crop.

From the plant species identified, 24 are hosts for M. hirsutus, 16 for P. solenopsis, one for $F$. virgata, one for $D$. brevipes and one for $P$. citri. (Table 1). From the species identified for M. hirsutus, 17 of them are recorded for the first time associated to this species of cochineal (García Morales et al. 2016): Amaranthus viridis, Commelina sp., Croton sonderianus, Cucumis anguria, Digitaria horizontalis, Herissanthia crispa, Jatropha urens, Mimosa caesalpineafolia, Mimosa tenuiflora, Momordica charantia, Piptadenia moniliformis, Serra macranthera, Sida cordifolia, Sida rhombifolia, Sonchus oleraceus, Talinum paniculatum and Ziziphus joazeiro (Table 1). During the study period, in the agroecosystems in question, $M$. hirsutus was

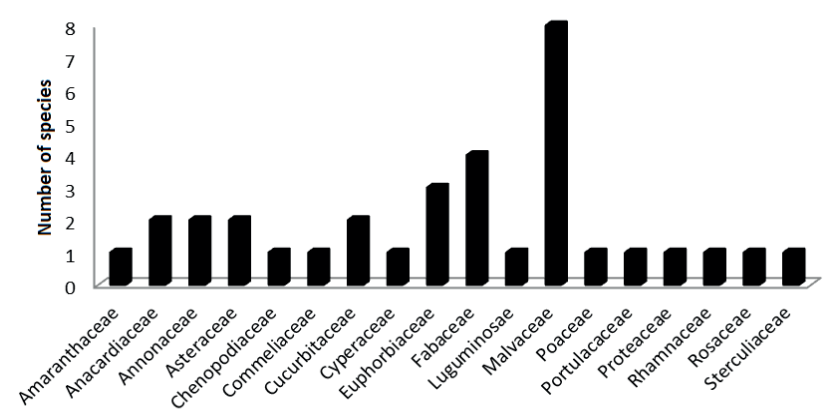

Figure 1. Families of alternative host plants for mealybugs in grapevine agroecosystems in the São Francisco Valley sub-region, Brazil. found to be more numerous, because of its recent introduction in the region (Lopes 2016).

$M$. hirsutus is highly polyphagous, with hosts distributed in 75 families in more than 211 genera (García Morales et al. 2016), with a preference for plants of the Fabaceae, Malvaceae and Moraceae families (Mani 1989), and may cause severe damage to economically important crops such as cotton, citrus, cocoa, coffee and grapes (Tambasco et al. 2000).

The geographic distribution, abundance, severity and attack of an invading insect are directly related to its ability to feed and reproduce on several hosts, as well as to its ability to adapt to the environment (Vennila et al. 2011). Thus, the population outbreak of $M$. hirsutus that occurred due to the recent introduction of this species in the region may have caused the displacement of other species of mealybugs due to direct or indirect interspecific competition (Reitz \& Trumble 2002).

Another species that was found in a higher proportion in host plants was $P$. solenopsis. This species is considered polyphagous and feeds on more than 200 species of plants, being distributed in approximately 60 families (García Morales et al. 2016). P. solenopsis has been reported in plants of the Asteraceae, Euphorbiaceae, Fabaceae, Malvaceae and Solanaceae families (Ibrahim et al. 2015).

For P. solenopsis, from 16 identified plants, 10 are new records of host plants for this species (García Morales et al. 2016): Chamaesyce hirta, Chenopodium ambrosioides, Commelina sp., D. horizontalis, S. cordifolia, S. galheirensis, Sidastrum micranthum, Sidastrum sp., T. paniculatum and Waltheria douradinha. For F. virgata, one first record of association with $S$. cordifolia has been already made (García Morales et al. 2016) (Table 1).

From the alternative host plants for mealybugs observed in the grapevine agroecosystems, 23 were classified as invasive or spontaneous weeds, which can be found in association with several crops of economic importance, including grapevine. Weeds are plant species that develop spontaneously, occurring in an undesirable location and, when present in agroecosystems, may interfere with economic crops, affecting the yield or quality of the harvested product (Vasconcelos et al. 2012). These plants can act by interfering in the areas of agricultural crops through competition, allelopathy and as hosts for pests and phytopathogenic agents. Consequently, the presence 
Table 1. Host plants (botanic family, species, Brazilian common name and status) and mealybugs associated in the São Francisco Valley region, Brazil.

\begin{tabular}{|c|c|c|c|}
\hline Family/Species & Common name & Status & Mealybug species \\
\hline \multicolumn{4}{|l|}{ Amaranthaceae } \\
\hline Amaranthus viridis & Bredo & Weed & Phenacoccus solenopsis \\
\hline \multicolumn{4}{|l|}{ Anacardiaceae } \\
\hline Mangifera indica & Manga [mango] & Exotic fruit tree & Maconellicoccus hirsutus \\
\hline Spondias tuberosa $\mathrm{x}$ Spondias mobin & Umbu-cajá & Exotic fruit tree & M. hirsutus \\
\hline S. tuberosa & Umbuzeiro & Native fruit tree & M. hirsutus \\
\hline \multicolumn{4}{|l|}{ Annonaceae } \\
\hline Annona muricata & Graviola & Exotic fruit tree & M. hirsutus \\
\hline Annona squamaosal & Pinha & Exotic fruit tree & M. hirsutus, Planococcus citri \\
\hline \multicolumn{4}{|l|}{ Asteraceae } \\
\hline Bidens pilosa & Picão-preto & Weed & M. hirsutus, $P$. solenopsis \\
\hline Sonchus oleraceus & Serralha & Weed & M. hirsutus, $P$. solenopsis \\
\hline \multicolumn{4}{|l|}{ Chenopodiaceae } \\
\hline Chenopodium ambrosioides & Mastruz & Weed & P. solenopsis \\
\hline \multicolumn{4}{|l|}{ Commeliaceae } \\
\hline Commelina sp. & Erva-de-Santa-Luzia & Weed & M. hirsutus, $P$. solenopsis \\
\hline \multicolumn{4}{|l|}{ Cucurbitaceae } \\
\hline Cucumis anguria & Maxixe-do-mato & Weed & M. hirsutus \\
\hline Momordica charantia & Melão-de-São-Caetano & Weed & M. hirsutus \\
\hline \multicolumn{4}{|l|}{ Cyperaceae } \\
\hline Cyperus rotundus & Tiririca & Weed & Dysmicoccus brevipes \\
\hline \multicolumn{4}{|l|}{ Euphorbiaceae } \\
\hline Chamaesyce hirta & Orelha-de-mexirra & Weed & P. solenopsis \\
\hline Croton sonderianus & Marmeleiro & Weed & M. hirsutus \\
\hline Jatropha urens & Cansanção & Weed & M. hirsutus \\
\hline \multicolumn{4}{|l|}{ Fabaceae } \\
\hline Mimosa caesalpineafolia & Sansão-do-campo & Windbreak plant & M. hirsutus \\
\hline Mimosa pudica & Malícia & Weed & M. hirsutus \\
\hline Mimosa tenuiflora & Jurema-preta & Native plant & M. hirsutus \\
\hline Piptadenia moniliformis & Angico-de-bezerro & Weed & M. hirsutus \\
\hline Serra macranthera & São-João & Weed & M. hirsutus \\
\hline \multicolumn{4}{|l|}{ Malvaceae } \\
\hline Herissanthia crispa & Malva-rasteira & Weed & P. solenopsis \\
\hline Hibiscus rosa-sinensis & Hibisco & Ornamental plant & M. hirsutus, $P$. solenopsis \\
\hline Sida cordifolia & Malva-branca & Weed & Ferrisia virgata, $M$. hirsutus, $P$. solenopsis \\
\hline Sida galheirensis & Malva-canela-de-siriema & Weed & P. solenopsis \\
\hline Sida rhombifolia & Guanxuma-relógio & Weed & P. solenopsis, M. hirsutus \\
\hline Sida sp. & Malva & Weed & P. solenopsis \\
\hline Sidastrum micranthum & Malva-preta & Weed & P. solenopsis \\
\hline Sidastrum $\mathrm{sp}$. & Malva & Weed & P. solenopsis \\
\hline \multicolumn{4}{|l|}{ Poaceae } \\
\hline Digitaria horizontalis & Capim-milã & Weed & M. hirsutus, $P$. solenopsis \\
\hline Grevillea robusta & Grevilha & Windbreak plant & M. hirsutus \\
\hline \multicolumn{4}{|l|}{ Portulacaceae } \\
\hline Talinum paniculatum & João-Gomes & Weed & M. hirsutus, $P$. solenopsis \\
\hline \multicolumn{4}{|l|}{ Rhamnaceae } \\
\hline Ziziphus joazeiro & Juazeiro & Native plant & M. hirsutus \\
\hline \multicolumn{4}{|l|}{ Rosaceae } \\
\hline Pyrus communis & Pera [pear] & Exotic fruit tree & M. hirsutus \\
\hline \multicolumn{4}{|l|}{ Sterculiaceae } \\
\hline Waltheria douradinha & Malva-da-flor-amarela & Weed & P. solenopsis \\
\hline
\end{tabular}


of weeds in vine growing areas may significantly increase pest infestation (Carvalho \& Costa 2014).

In relation to weeds, there was a predominance of species of the Malvaceae family. In previous studies, plants of this family were also identified as hosts for P. solenopsis in cotton crops, and 12 species of the Malvaceae family were reported as hosts for that mealybug, in addition to other families such as Asteraceae, Lamiaceae, Euphorbiaceae and Poaceae (Vennila et al. 2013). In studies by Abbas et al. (2010), 55 species of alternative host plants associated with $P$. solenopsis were identified in cotton crops and classified according to infestation. These plants were mainly distributed among the Asteraceae, Malvaceae and Solanaceae families. The species with the highest infestation rate was Hibiscus rosa-sinensis L. (Malvaceae), with an average of $96.4 \%$.

When grapevines are infested by weed species, it is important to plan the elimination of these plants in the vicinity of the pest outbreaks, in order to prevent migration, by spraying the places of refuge and survival (Benvenga et al. 2011). In pineapple crops, a total of 17 weed species associated with $D$. brevipes, belonging to the Asteraceae, Brassicaceae, Euphorbiaceae, Fabaceae, Poaceae and Plantoginacea families (Pandey \& Johnson 2006), were recorded.

Weeds are always associated with practically all crop systems, and it is important to develop possible control tactics, especially cultural ones, of mealybugs that live in those plants (Vennila et al. 2013). Methods that aim to reduce the amount of weeds in crops, such as weeding, and the use of herbicides may contribute to reducing mealybug populations. In this way, mealybugs are exposed to the action of predators and may dislodge ants that transport nymphs to other sites, thus limiting their propagation, minimizing mealybug populations and consequently their damages (TachieMenson et al. 2014).

Maconelicoccus hirsutus was the only mealybug species associated with plants used as windbreaks in the grapevine agroecosystems in the region. Two plant species [Mimosa caesalpiniaefolia Benth ("sabiá" or "sansão-do-campo"), also considered a native plant, and Grevillea robusta Cunn. (silk oak or silver oak)] were identified, the latter being frequently used as a windbreak plant in orchards and vineyards (Conceição 1996). The $G$. robusta species has been reported as host for M. hirsutus in other countries (García Morales et al. 2016). These plants are used quite often as windbreaks in grapevines in the region. Windbreak plants are important for the protection of crops, especially young crops, because they avoid the rupture of shoots, which would hinder the branch orientation and cause deformations in the plant structure (Nachtigal et al. 2005). In the visited areas, high infestations of $M$. hirsutus were found in windbreak plants, which may be serving as reservoirs for mealybugs.

In native plants, the species associated with high infestations of mealybugs were Mimosa tenuiflora (Wild) Poir., Ziziphus joazeiro Mart., Spondias tuberosa L. and M. caesalpineafolia.

The control of mealybugs in grapevine producing areas in alternative host plants is a great challenge. Currently, in the region, the management of this pest has been carried out by pruning and burning weed structures and infested windbreaks, in addition to the control carried out directly on vine plants. However, the use of other control methods is necessary to halt the pest. The chemical control is the fastest method, and the most effective synthetic insecticides are reported for Eurhizococcus brasiliensis (Hempel) in grapevine crops (Agrofit 2018). Therefore, there is a need to register products for the mealybug species occurring in that crop, mainly in M. hirsutus. Another bottleneck for the $M$. hirsutus control is its occurrence on native M. tenuiflora, which was found in great densities near the crops in all the visited sites. It was observed that infested plants possibly act as mealybug foci, being carried by the wind to crops. Accordingly, even after the $M$. hirsutus control on the vine, the proximity of native plants infested implies a risk of reinfestation.

In exotic fruit trees species, such as Annona muricata L., Annona squamosa L., Mangifera indica L., Pyrus communis L. and Spondias tuberosa $\mathrm{X} S$. mombin, found near the crops, the presence of $M$. hirsutus was also observed. The occurrence of this mealybug species has been previously reported for these same fruit tree species in other countries (García Morales et al. 2016). In all identified plants, this mealybug species was found in high infestations. The presence of plants intercropped with grapevine, as in the case of pineapple, requires adequate phytosanitary measures, avoiding the infestation focus (Souza et al. 2001).

In the ornamental plant Hibiscus sp., the presence of $M$. hirsutus, known as hibiscus mealybug, 
was also observed. This plant was located at the entrance of the rows of grape plants and also close to the crops, what facilitated the infestation in the vine. This plant is often found with natural infestations of M. hirsutus (Persad \& Khan 2007), and the $M$. hirsutus species was also reported as host for P. solenopsis (Venilla et al. 2014).

Some mealybugs species that occur in grapevine crops have been reported for several host plants species. Planococcus minor (Maskell, 1897) has been reported for sesame, peanut, watermelon, guava and some spontaneous plants, such as white mauve [Sida carpinifolia L. (Malvales: Malvaceae)], Indian heliotrope [Heliotropium indicum L. (Boraginales: Boraginaceae)], asthma-plant [Euphorbia hirta L. (Malpighiales: Euphorbiaceae)], spiny amaranth [Amaranthus sp. (Caryophyllales: Amaranthaceae)] and white jurubeba [Solanum paniculatum L. (Solanales: Solanaceae)] (Bastos et. al. 2007). P. citri was reported in Egypt in 65 plant species, distributed in 36 families; among them fruit plants, such as Mangifera indica L. and Pyrus communis L., and weeds, such as Cyperus sp. (Ahmed \& Abd-Rabou 2010).

However, in addition to mealybugs, many alternative host plant species present in grapevine agroecosystems may contain a high number of beneficial insects, serving also as reservoirs of natural enemies for the control of crop-related pests. In this way, these plants can be used in places where strategies of applied biological control programs are adopted (Diehl et al. 2012).

Alternative host plant species are found very close to or within the crop, what may facilitate the dispersion of these mealybug species to the crops. Thus, management programs for the mealybug species imply the need to monitor alternative host plants.

The results of this study shall make important contributions for the background on the diversity of host plants for mealybugs in grapevine crops in the São Francisco Valley region, Brazil. In addition, the identification of plant species that are potential reservoirs of these grapevine pests provides subsidies for the correspondent implementation of integrated pest management programs.

\section{CONCLUSION}

Some mealybugs species, especially Maconellicoccus hirsutus and Phenacoccus solenopsis, are found infesting weeds, windbreak plants and some fruit trees around and into grapevine crops in the São Francisco Valley region, Brazil. These plants belong mainly to the Malvaceae, Euphorbiaceae and Fabaceae families, and most of them are recorded here for the first time in association with mealybugs (e.g., Herissanthia crispa, Jatropha urens and Mimosa tenuiflora associated with M. hirsutus; and Chamaesyce hirta, Sida galheirensis and Sidastrum micranthum with P. solenopsis). In a pest integrated management program, these host plants need to be adequately controlled to avoid the re-infestation of commercial orchards.

\section{REFERENCES}

ABBAS, G. et al. Host plants, distribution and overwintering of cotton mealybug (Phenacoccus solenopsis; Hemiptera: Pseudococcidae). International Journal of Agriculture and Biology, v. 12, n. 3, p. 421-425, 2010.

AGROFIT: sistema de agrotóxicos fitossanitários. 2003. Available at: <http://agrofit.agricultura.gov.br/agrofit cons/principal_agrofit_cons $>$. Access on: 14 jun. 2018.

AHMED, N. H.; ABD-RABOU, S. M. Host plants, geographical distribution, natural enemies and biological studies of the citrus mealybug, Planococcus citri (Risso) (Hemiptera: Pseudococcidae). Egyptian Academic Journal of Biological Sciences, v. 3, n. 1, p. 39-47, 2010.

BASTOS, C. S. et al. Ocorrência de Planococcus minor Maskell (Hemiptera: Pseudococcidae) em algodoeiro no Nordeste do Brasil. Neotroprical Entomology, v. 36, n. 4, p. 625-628, 2007.

BENVENGA, S. R. et al. Manejo prático da cochonilha ortézia em pomares de citros. Citrus Research \& Technology, v. 32, n. 1, p. 39-52, 2011.

CABALEIRO, C.; SEGURA, A. Some characteristics of the transmission of grapevine leafroll associated virus 3 by Planococcus citri Risso. European Journal of Plant Pathology, v. 103, n. 4, p. 373-378, 1997.

CARVALHO, L. B.; COSTA, F. R. Interferência de plantas daninhas. In: CARVALHO, L. B. (Ed.). Monitoramento e manejo de plantas daninhas em videiras de altitude. Lajes: Ed. do Autor, 2014. p. 1-9.

CID, M. et. al. Presence of grapevine leafroll-associated virus 3 in primary salivary glands of the mealybug vector Planococcus citri suggests a circulative transmission mechanism. European Journal of Plant Pathology, v. 118, n. 1, p. 23-30, 2007.

CONCEIÇÃO, M. A. F. Critérios para a instalação de quebra-ventos. Jales: Embrapa, 1996. 
DAANE, K. M. et al. Biology and management of mealybugs in vineyards. In: BOSTANIAN, N. J.; VINCENT, C.; ISAACS, R. (Eds.). Arthropod management in vineyards: pests, approaches, and future directions. Dordrecht: Springer, 2012. p. 271-307.

DAANE, K. M. et al. Vineyard managers and researchers seek sustainable solutions for mealybugs, a changing pest complex. California Agriculture, v. 62, n. 4, p. 167-176, 2008 .

DIEHL, M.; FERLA, N. J.; JOHANN, L. Plantas associadas a videiras: uma estratégia para o controle biológico no Rio Grande do Sul. Arquivos do Instituto Biológico, v. 79, n. 4, p. 579-586, 2012.

GARCÍA MORALES, M. et al. ScaleNet: a literaturebased model of scale insect biology and systematics. 2016. Available at: <http://scalenet.info/>. Access on: 9 May 2016.

GODFREY, K. et al. Biology of the vine mealybug in vineyards in the Coachella Valley. California Southwest Entomology, v. 28, n. 3, p. 183-196, 2003.

GRANARA DE WILLINK, M. C. Conociendo nuestra fauna I: superfamilia Coccoidea (Homoptera: Sternorrhyncha). Tucumán: Universidad Nacional de Tucumán, 1990.

GRANARA DE WILLINK, M. C. Dysmicoccus de la región neotropical (Hemiptera: Pseudococcidae). Revista de la Sociedad Entomológica Argentina, v. 68, n. 1-2, p. 11-95, 2009.

GULLAN, P. J.; KAYDAN, M. B.; HARDY, N. B. Molecular phylogeny and species recognition in the mealybug genus Ferrisia Fullaway (Hemiptera: Pseudococcidae). Systematic Entomology, v. 35, n. 2, p. 329-339, 2010.

IBRAHIM, S. S.; MOHARUM, F. A.; EL-GHANY, N. M. A. The cotton mealybug Phenacoccus solenopsis Tinsley (Hemiptera: Pseudococcidae) as a new insect pest on tomato plants in Egypt. Journal of Plant Protection Research, v. 55, n. 1, p. 48-51, 2015.

KAYDAN, M. B.; GULLAN, P. J. A taxonomic revision of the mealybug genus Ferrisia Fullaway (Hemiptera: Pseudococcidae), with descriptions of eight new species and a new genus. Zootaxa, v. 3543, n. 1, p. 1-65, 2012.

KISHINO, A. Y.; CARVALHO, S. L. C.; ROBERTO, S. R. Viticultura tropical: o sistema de produção do Paraná. Londrina: Instituto Agronômico do Paraná, 2007.

KISSMANN, K. G. Plantas infestantes e nocivas: inferiores-monocotiledôneas. São Paulo: BASF Brasileira, 1991.
KISSMANN, K. G.; GROTH, D. Plantas infestantes e nocivas: plantas dicotiledôneas. São Paulo: BASF Brasileira, 1992.

LOPES, F. S. C. Bioprospecção, identificação e manejo de cochonilhas-farinhentas (Hemiptera: Pseudococcidae) e insetos associados em agroecossistemas de videira no submédio do Vale do São Francisco. 2016. 150 f. Tese (Doutorado em Entomologia Agrícola) - Universidade Federal Rural de Pernambuco, Recife, 2016.

MANI, M. Areview of the pink mealybug: Maconellicoccus hirsutus. Insect Science and its Application, v. 10, v. 2, p. 157-167, 1989.

MAZIERO, H. et. al. Plantas infestantes hospedeiras de Rhopalosiphum rufiabdominalis (Sasaki) (Hemiptera: Aphididae) em áreas de cultivo de arroz irrigado. Neotroprical Entomology, v. 36, n. 3, p. 471-472, 2007.

MORANDI FILHO, W. J. et. al. A survey of mealybugs infesting south-Brazilian wine vineyards. Revista Brasileira de Entomologia, v. 59, n. 3, p. 251-254, 2015.

NACHTIGAL, J. C.; CAMARGO, U. A.; MAIA, J. D. G. Implantação do vinhedo: sistema de produção de uva de mesa no norte do Paraná. 2005. Available at: <https:// sistemasdeproducao.cnptia.embrapa.br/FontesHTML/ Uva/MesaNorteParana/implantacao.htm\#formacao>. Access on: 23 May 2016.

PANDEY, R. R.; JOHNSON, M. W. Weeds adjacent to Hawaiian pineapple plantings harboring pink pineapple mealybugs. Environmental Entomology, v. 35, n. 1, p. 6874, 2006.

PERSAD, A.; KHAN, A. Effects of four host plants on biological parameters of Maconellicoccus hirsutus Green (Homoptera: pseudococcidae) and efficacy of Anagyrus kamali Moursi (Hymenoptera: Encyrtidae). Journal of Plant Protection Research, v. 47, n. 1, p. 35-42, 2007.

REITZ, S. R.; TRUMBLE, J. T. Competitive displacement among insects and arachnids. Annual Review of Entomology, v. 47, n. 1, p. 435-465, 2002.

SOUZA, J. C. et al. Cochonilha-da-raiz do cafeeiro: aspectos biológicos, dano e controle. Lavras: Epamig, 2001.

TACHIE-MENSON, J. W.; SARKODIE-ADDO, J.; CARLSON, A. G. Effects of weed management on the prevalence of pink pineapple mealybugs in Ghana. Journal of Science and Technology, v. 34, n. 2, p. 17-25, 2014.

TAMBASCO, F. J. et al. Cochonilha rosada, Maconellicoccus hirsutus (Green): uma praga de importância quarentenária já se encontra na Guiana Inglesa. Floresta, v. 30, n. 1/2, p. 85-93, 2000.

VASCONCELOS, M. C. C.; SILVA, A. F. A.; LIMA, R. S. Interferência de plantas daninhas sobre plantas cultivadas. Agropecuária Científica no Semiárido, v. 8, n. 1, p. 1-6, 2012. 
VENNILA, S. et al. Spatio-temporal distribution of hosts plants of cotton mealybug, Phenacoccus solenopsis Tinsley in India. New Delhi: NCIPM, 2011.

VENNILA, S. et. al. Ornamental hosts of cotton mealybug (Phenacoccus solenopsis). Indian Journal of Agricultural Sciences, v. 84, n. 1, p. 161-163, 2014.
VENNILA, S. et. al. Weed hosts of cotton mealybug, Phenacoccus solenopsis Tinsley (Hemiptera: Pseudococcidae). Journal of Environmental Biology, v. 34, n. 2, p. 153-158, 2013.

WILLIAMS, D. J.; GRANARA DE WILLINK, M. C. Mealybugs of Central and South America. London: CAB International, 1992. 